\title{
Up-Regulation of the Excitatory Amino Acid Transporters EAAT1 and EAAT2 by Mammalian Target of Rapamycin
}

\author{
Abeer Abousaaba Nestor Luis Uzcategui ${ }^{b} \quad$ Bhaeldin Elsir ${ }^{c}$ Florian Langa,d \\ aDepartment of Cardiology, Vascular Medicine and Physiology I, University of Tuebingen, Tuebingen,

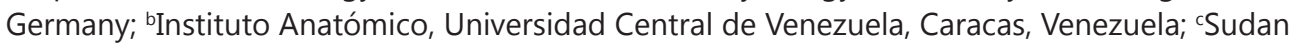 \\ University of Science and Technology, Khartoum, Sudan; ${ }^{d}$ Department of Molecular Medicine II, \\ Heinrich Heine University Düsseldorf, Germany
}

\section{Key Words}

Neuroexcitability • Glutamate transporter $\cdot \mathrm{SLC1A3} \cdot \mathrm{SLC1A} 2$

\begin{abstract}
Background: The excitatory amino-acid transporters EAAT1 and EAAT2 clear glutamate from the synaptic cleft and thus terminate neuronal excitation. The carriers are subject to regulation by various kinases. The EAAT3 isoform is regulated by mammalian target of rapamycin (mTOR). The present study thus explored whether mTOR influences transport by EAAT1 and/or EAAT2. Methods: CRNA encoding wild type EAAT1 (SLC1A3) or EAAT2 (SLC1A2) was injected into Xenopus oocytes without or with additional injection of CRNA encoding mTOR. Dual electrode voltage clamp was performed in order to determine electrogenic glutamate transport ( $\mathrm{I}_{\text {EAAT }}$ ). EAAT2 protein abundance was determined utilizing chemiluminescence. Results: Appreciable $\mathrm{I}_{\text {EAAT }}$ was observed in EAAT1 or EAAT2 expressing but not in water injected oocytes. I $\mathrm{IAAT}_{\text {EA }}$ was significantly increased by coexpression of mTOR. Coexpression of mTOR increased significantly the maximal $\mathrm{I}_{\text {EAAT }}$ in EAAT1 or EAAT2 expressing oocytes, without significantly modifying affinity of the carriers. Moreover, coexpression of mTOR increased significantly EAAT2 protein abundance in the cell membrane. Conclusions: The kinase mTOR up-regulates the excitatory amino acid transporters EAAT1 and EAAT2.

\section{Introduction}

Excitatory amino acid transporters clear glutamate and aspartate from synaptic clefts and thus participate in the termination of neuronal excitation as well as protection against excitotoxicity [1-5]. The excitatory amino acid transporter isoforms EAAT1 and EAAT2 are 
the most important carriers clearing glutamate and aspartate following excitation [6]. EAAT1 primarily mediates glutamate uptake into glial cells [1]. The carrier is, however, not only expressed in astrocytes [7-15] and oligodendrocytes [16, 17], but in addition in neurons [18$20]$, retina [21, 22], taste buds [23], cochlea [24, 25], vestibular organ [26], circumventricular organ [7], as well as adrenal and pineal glands [27,28]. EAAT2 is expressed in astrocytes [29] and accomplishes glial uptake of excitatory amino acids from the synaptic cleft [30]. Upregulation of EAAT2 activity provides neuroprotection [31] and impaired expression or activity of EAAT2 leads to extracellular glutamate accumulation and neuroexcitotoxicity [32-35].

The EAAT3 excitatory amino acid transporter isoform is regulated by mammalian target of Rapamycin (mTOR) [36], a serine/threonine kinase stimulated by growth factors [37], insulin [38], leptin [39], and nutrients [40]. The kinase is down-regulated by hypoxia [41] and contributes to the regulation of cell proliferation, cell growth and cell survival [37, $40,42]$.

The present study explored whether the glutamate transporters EAAT1 (SLC1A3) or EAAT2 (SLC1A2) are similarly sensitive to mTOR. To this end, EAAT1 or EAAT2 were expressed in Xenopus oocytes without and with additional expression of mTOR. Glutamate transport was quantified by measurement of glutamate-induced current, as determined by dual electrode voltage clamp.

\section{Materials and Methods}

\section{Constructs}

For generation of cRNA [43, 44], constructs were used encoding wild-type mTOR [45], EAAT1 [46] and EAAT2 [47-49]. The constructs were sequenced to verify the correctness of the plasmid [50]. The constructs were used for generation of cRNA as described previously [51-53].

Voltage clamp in Xenopus oocytes

Xenopus oocytes were prepared as previously described [54-56]. 10 ng of wild type mTOR cRNA were injected one day after preparation of the oocytes and 10 ng EAAT1 or EAAT2 cRNA was injected one day after mTOR injection. The oocytes were maintained at $17^{\circ} \mathrm{C}$ in a solution containing (in $\mathrm{mM}: 96 \mathrm{NaCl}, 4 \mathrm{KCl}$, 1.8 $\mathrm{MgC1}_{2}, 0.1 \mathrm{CaC1}_{2}, 5$ HEPES, pH 7.4, supplemented with theophyllin (90 mg/l), gentamycin (100 mg/l), tetracyclin $(50 \mathrm{mg} / \mathrm{l})$ and ciprofloxacin $(1.6 \mathrm{mg} / \mathrm{l})$. The final solutions were titrated to $\mathrm{pH} 7.4 \mathrm{using} \mathrm{NaOH}$. The voltage clamp experiments [57-59] were performed at room temperature 6 days after injection. Two-electrode voltage-clamp recordings were performed at a holding potential of $-70 \mathrm{mV}$. The data were filtered at $10 \mathrm{~Hz}$ and recorded with a Digidata A/D-D/A converter (1322A Axon Instruments) and Clampex 9.2 software for data acquisition and analysis (Axon Instruments) [60-62]. The control superfusate contained $96 \mathrm{mM} \mathrm{NaCl}, 2 \mathrm{mM}$ $\mathrm{KCl}, 1.8 \mathrm{mM} \mathrm{CaCl}_{2}, 1 \mathrm{mM} \mathrm{MgCl}$ and $5 \mathrm{mM}$ HEPES, pH 7.4. Glutamate was added to the solutions at the indicated concentrations. The flow rate of the superfusion was approx. $20 \mathrm{ml} / \mathrm{min}$, and a complete exchange of the bath solution was reached within about $10 \mathrm{~s}$ [63-65].

\section{Detection of EAAT2 cell surface expression by chemiluminescence}

For detection of EAAT2 cell surface expression, defolliculated oocytes were incubated during 1hour atroom temperature with rabbit anti- EAAT2 antibody (diluted 1:500, Alamone labs, Israel), washed and subsequently incubated with secondary, HRP-conjugated, goat anti-rabbit IgG antibody (1:1000, Cell Signaling technology, USA). After washing the second anti-body, oocytes were placed in 96 well plates for chemiluminescence assay with the SuperSignal ELISA Femto Maximum Sensitivity Substrate (Pierce, Rockford, IL, USA), following the manufacturer's recommendations. Chemiluminescence of each oocyte was determined in a luminometer (Walter Wallac 2 plate reader, Perkin Elmer, Juegesheim, Germany) [36].

\section{Statistical analysis}

Data are provided as means \pm SEM, $n$ represents the number of oocytes investigated. All experiments were repeated with at least 3 batches of oocytes; in all repetitions qualitatively similar data were obtained. As expression of EAAT and/or mTOR may vary from batch to batch of oocytes, comparisons were always made 


\section{Cellular Physiology Cell Physiol Biochem 2016;39:2492-2500 \begin{tabular}{l|l|l} 
and Biochemistry Published ondine: November 14, 2016 & $\begin{array}{l}\text { (c) } 2016 \text { The Author(s). Published by S. Karger AG, Basel } \\
\text { www.karger.com/cpb }\end{array}$
\end{tabular} \\ Abousaab et al.: mTor Sensitive EAAT1 and EAAT2}

within the same oocyte batch $[66,67]$. Data were tested for significance using ANOVA or t-test, as appropriate. Results with $\mathrm{p}<0.05$ were considered statistically significant.

\section{Results}

The present study analyzed the effect of mammalian target of rapamycin (mTOR) on glutamate transport by the excitatory amino acid transporters EAAT1 and EAAT2. To this end, cRNA encoding EAAT1 or EAAT2 was injected into Xenopus laevis oocytes with or without additional injection of cRNA encoding mTOR. Glutamate induced current determined by dual electrode voltage clamp was taken as measure of transport.

As shown in Fig. 1, addition of glutamate to the superfusate did not elicit an appreciable current in water-injected oocytes. Accordingly, the oocytes did not express significant endogenous electrogenic glutamate transport. In EAAT1 expressing oocytes, however, the addition of glutamate to the superfusate was followed by the appearance of a large inward current. The additional co-expression of wild-type mTOR was followed by a significant increase of glutamate induced current in EAAT1 expressing Xenopus laevis oocytes.

In order to test whether mTOR co-expression modifies the maximal glutamate induced current or the affinity of the carrier, the current induced by glutamate concentrations ranging from $1 \mu \mathrm{M}$ to $5 \mathrm{mM}$ was determined in Xenopus laevis oocytes expressing EAAT1 without or with additional expression of mTOR. As illustrated in Fig. 2, the glutamate induced current was a function of the extracellular glutamate concentration. Kinetic analysis revealed that the maximal glutamate induced current was significantly $(p<0.001)$ lower in Xenopus laevis oocytes expressing EAAT1 alone $(71.92 \pm 6.79 \mathrm{nA}, \mathrm{n}=7)$ than in Xenopus laevis oocytes expressing EAAT1 together with mTOR $(118.6 \pm 6.0 \mathrm{nA}, \mathrm{n}=7)$. The concentration required for half-maximal glutamate induced current was not significantly different between Xenopus oocytes expressing EAAT1 alone (379.51 $\pm 59.97 \mu \mathrm{M}, \mathrm{n}=7)$ and Xenopus oocytes expressing EAAT1 together with wild-type mTOR $(536.54 \pm 112.07 \mu \mathrm{M}, \mathrm{n}=7)$.

Similar observations were made with EAAT2. In EAAT2 expressing oocytes, the addition of glutamate to the superfusate was again followed by appearance of a large inward current (Fig. 3). The additional co-expression of wild-type mTOR was followed by a significant increase of glutamate induced current in EAAT2 expressing Xenopus laevis oocytes (Fig. 3).

Again, a kinetic analysis was made to test whether mTOR co-expression modifies the maximal glutamate induced current or the affinity of the carrier. To this end, the current

Fig. 1. Effect of $\mathrm{mTOR}$ on electrogenic glutamate transport in EAAT1 expressing Xenopus laevis oocytes. A: Representative original tracings showing glutamate $(1 \mathrm{mM})$ - induced current $\left(\mathrm{I}_{\mathrm{EAAT}}\right)$ in Xenopus laevis oocytes injected with water (a) or expressing EAAT1 (SLC1A3) without (b) or with (c) additional co-expression of mTOR. B: Arithmetic means \pm $\operatorname{SEM}(\mathrm{n}=14-16)$ of $\mathrm{I}_{\text {EAAT }}$

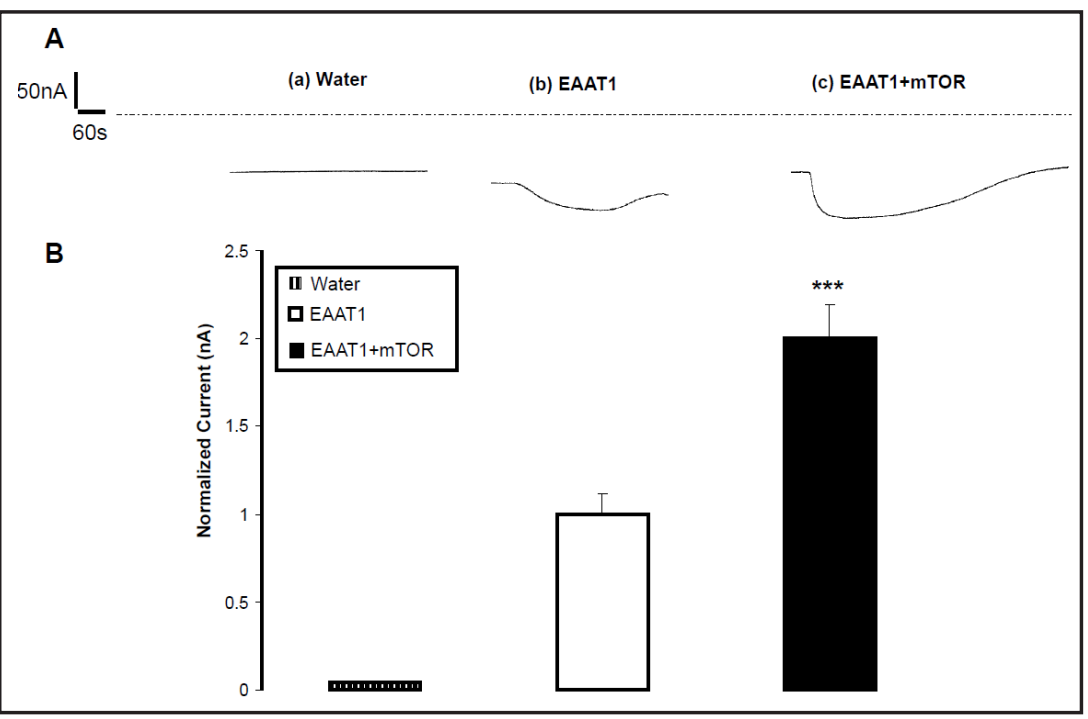
in Xenopus laevis oocytes injected with water (striated bar), or expressing EAAT3 without (white bar) or with mTOR (black bar). ${ }^{* * *}(p<0.001)$ indicates statistically significant difference from the absence of mTOR. 
Fig. 2. Electrogenic glutamate transport in EAAT1expressing Xenopus laevis oocytes as a function of glutamate concentration without and with presence of mTOR. Arithmetic means \pm SEM ( $n=7)$ of $\mathrm{I}_{\mathrm{EAAT}}$ as a function of glutamate concentration in Xenopus laevis oocytes expressing EAAT1 without (black squares), or with (black circles) additional co-expression of mTOR.

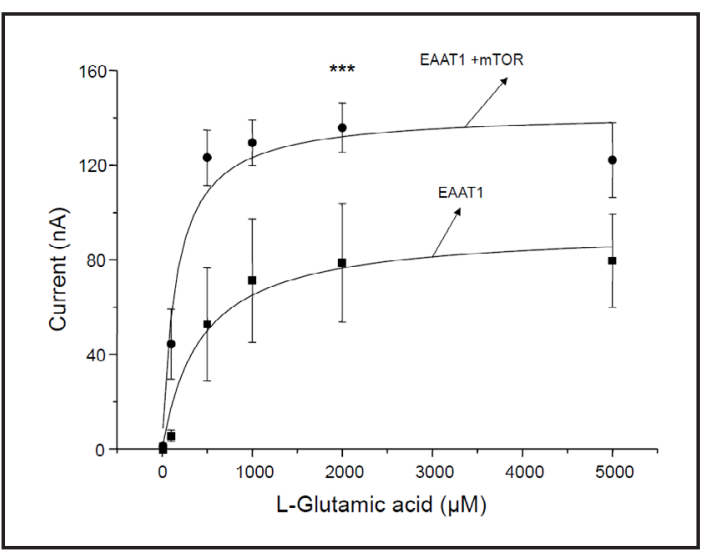

Fig. 3. Effect of mTOR on electrogenic glutamate transport in EAAT2 expressing Xenopus laevis oocytes. Arithmetic means \pm SEM $(\mathrm{n}=11-15)$ of $\mathrm{I}_{\text {EAAT }}$ in Xenopus laevis oocytes injected with water (striated bar), or expressing EAAT2 without (white bar) or with mTOR (black bar). *** $(p<0.001)$ indicates statistically significant difference from the absence of mTOR.

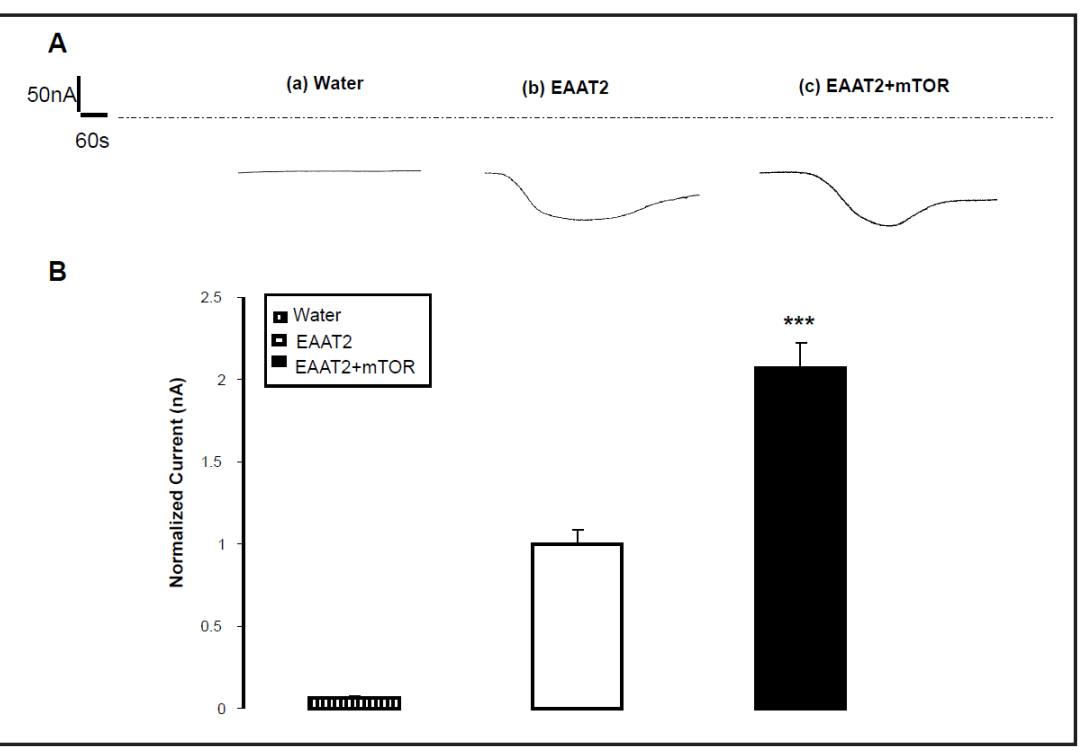

Fig. 4. Electrogenic glutamate transport in EAAT2expressing Xenopus laevis oocytes as a function of glutamate concentration without and with presence of mTOR. Arithmetic means \pm SEM $(n=6-7)$ of $\mathrm{I}_{\text {EAAT }}$ as a function of glutamate concentration in Xenopus laevis oocytes expressing EAAT2 without (black squares), or with (black circles) additional co-expression of wild-type mTOR.

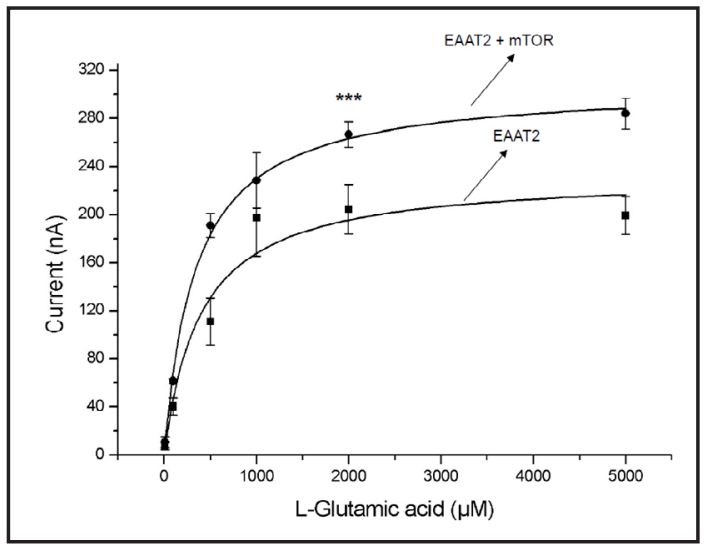

induced by glutamate concentrations ranging from $1 \mu \mathrm{M}$ to $5 \mathrm{mM}$ was determined in Xenopus laevis oocytes expressing EAAT2 without or with additional expression of mTOR. As illustrated in Fig. 4, the glutamate induced current was a function of the extracellular 


\section{Cellular Physiology Cell Physiol Biochem 2016;39:2492-2500

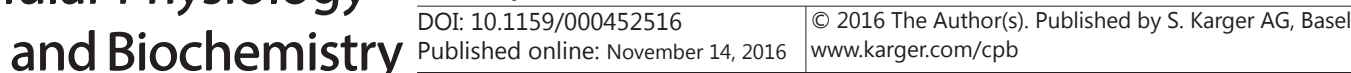 \\ Abousaab et al.: mTor Sensitive EAAT1 and EAAT2}

Fig. 5. Effect of mTOR on EAAT2 abundance within the plasma membrane of oocytes. EAAT2 cell surface expression was assessed by chemiluminescence in Xenopus oocytes injected with water (striated bar), or with EAAT2 without (white bar) or with additional co-expression of mTOR (black bar). ${ }^{* * *}$ indicates statistically significant difference to oocytes expressing EAAT2 alone $(p<0.001)(n=51-58)$. Data were normalized using the chemiluminiscence signal of EAAT2 alone, as reference.

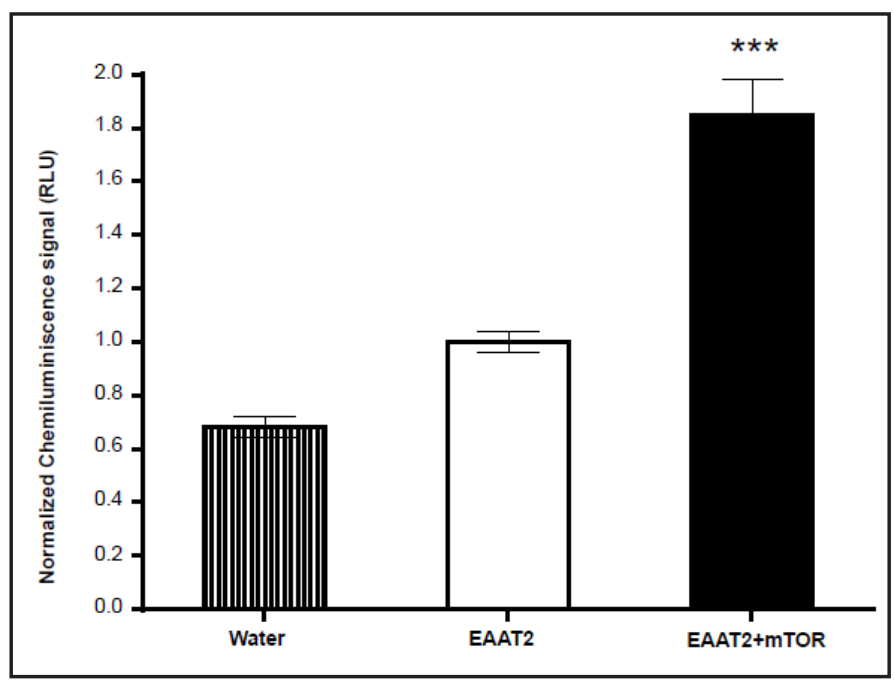

glutamate concentration. The calculated maximal glutamate induced current was significantly $(p<0.001)$ lower in Xenopus laevis oocytes expressing EAAT2 alone $(62.79 \pm 6.62 \mathrm{nA}, \mathrm{n}=6)$ than in Xenopus laevis oocytes expressing EAAT2 together with wild-type mTOR (96.50 \pm $7.98 \mathrm{nA}, \mathrm{n}=7$ ). The concentration required for half-maximal glutamate induced current was not significantly different between Xenopus oocytes expressing EAAT2 alone (512.75 \pm 32.56 $\mu \mathrm{M}, \mathrm{n}=6)$ and Xenopus oocytes expressing EAAT2 together with mTOR $(489.70 \pm 102.71 \mu \mathrm{M}$, $\mathrm{n}=7$ ).

At least in theory, the increase of $I_{\text {glu }}$ in EAAT2 expressing oocytes following coexpressing of mTOR could have resulted from an increase of carrier protein abundance in the cell membrane. Thus, chemiluminescence analysis was employed to test for altered carrier protein abundance within the cell surface. As illustrated in Fig. 5, the coexpression of mTOR indeed significantly increased the EAAT2 protein abundance in the cell membrane. The enhanced EAAT2 protein abundance in the cell membrane of EAAT2 and mTOR coexpressing oocytes could have resulted from either, accelerated insertion of new carriers into the cell membrane, or delayed clearance of carriers from the cell membrane.

\section{Discussion}

The present observations disclose a novel function of the mammalian target of rapamycin (mTOR), i.e. the up-regulation of the excitatory amino acid transporters EAAT1 and EAAT2. Coexpression of mTOR increased electrogenic glutamate transport in EAAT1 and EAAT2 expressing Xenopus oocytes. Coexpression of mTOR increased the maximal glutamate induced current in EAAT1 or EAAT2 expressing oocytes, without significantly modifying affinity of the carriers. According to chemiluminescence, mTOR increases the abundance of carrier protein in the plasma membrane.

By up-regulating the excitatory amino acid transporters, mTOR could accelerate the clearance of the excitatory amino acids glutamate and aspartate from the synaptic cleft and thus accelerate termination of excitation. Additional experimental effort is, however, required in order to define the functional significance of mTOR sensitive excitatory amino acid transport for the complex regulation of neuroexcitation.

In addition to neuronal, glial and sensory cells, EAAT1 is expressed in bone cells [68-71], and at least in theory, mTOR sensitive glutamate and/or aspartate transport may modify the function of those cells.

In conclusion, mTOR is a powerful stimulator of the excitatory amino acid transporters EAAT1 and EAAT2, an effect due to increase of carrier protein abundance in the cell membrane. The kinase may thus contribute to the fine tuning of neuronal excitation. 


\section{Cellular Physiology Cell Physiol Biochem 2016;39:2492-2500

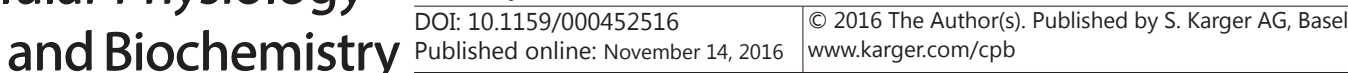 Abousaab et al.: mTor Sensitive EAAT1 and EAAT2}

\section{Acknowledgements}

The authors acknowledge the meticulous preparation of the manuscript by Lejla Subasic and technical support by Elfriede Faber. Abeer Abousaab and Nestor L. Uzcategui are supported by the Deutsche Akademische Austauschdienst (DAAD) and the Alexander von Humboldt Foundation, respectively. The study was further supported by the Deutsche Forschungsgemeinschaft and Open Access Publishing Fund of Tuebingen University.

\section{Disclosure Statement}

None.

\section{References}

1 Beart PM, O'Shea RD: Transporters for L-glutamate: an update on their molecular pharmacology and pathological involvement. Br J Pharmacol 2007;150:5-17.

2 Estrada Sanchez AM, Mejia-Toiber J, Massieu L: Excitotoxic neuronal death and the pathogenesis of Huntington's disease. Arch Med Res 2008;39:265-276.

3 Foran E, Trotti D: Glutamate transporters and the excitotoxic path to motor neuron degeneration in amyotrophic lateral sclerosis. Antioxid Redox Signal 2009;11:1587-1602.

4 Markowitz AJ, White MG, Kolson DL, Jordan-Sciutto KL: Cellular interplay between neurons and glia: toward a comprehensive mechanism for excitotoxic neuronal loss in neurodegeneration. Cellscience 2007;4:111-146.

5 Sheldon AL, Robinson MB: The role of glutamate transporters in neurodegenerative diseases and potential opportunities for intervention. Neurochem Int 2007;51:333-355.

6 Amara SG, Fontana AC: Excitatory amino acid transporters: keeping up with glutamate. Neurochem Int 2002;41:313-318.

7 Berger UV, Hediger MA: Comparative analysis of glutamate transporter expression in rat brain using differential double in situ hybridization. Anat Embryol (Berl) 1998;198:13-30.

8 Cholet N, Pellerin L, Magistretti PJ, Hamel E: Similar perisynaptic glial localization for the Na+,K+-ATPase alpha 2 subunit and the glutamate transporters GLAST and GLT- 1 in the rat somatosensory cortex. Cereb Cortex 2002;12:515-525.

9 Fukaya M, Yamada K, Nagashima M, Tanaka K, Watanabe M: Down-regulated expression of glutamate transporter GLAST in Purkinje cell-associated astrocytes of reeler and weaver mutant cerebella. Neurosci Res 1999;34:165-175.

10 Kimmich GA, Roussie J, Manglapus M, Randles J: Characterization of Na+-coupled glutamate/aspartate transport by a rat brain astrocyte line expressing GLAST and EAAC1. J Membr Biol 2001;182:17-30.

11 Sandhu JK, Sikorska M, Walker PR: Characterization of astrocytes derived from human NTera-2/D1 embryonal carcinoma cells. J Neurosci Res 2002;68:604-614.

12 Suarez I, Bodega G, Fernandez B: Modulation of glutamate transporters (GLAST, GLT-1 and EAAC1) in the rat cerebellum following portocaval anastomosis. Brain Res 2000;859:293-302.

13 Suzuki K, Ikegaya Y, Matsuura S, Kanai Y, Endou H, Matsuki N: Transient upregulation of the glial glutamate transporter GLAST in response to fibroblast growth factor, insulin-like growth factor and epidermal growth factor in cultured astrocytes. J Cell Sci 2001;114:3717-3725.

14 Ullensvang K, Lehre KP, Storm-Mathisen J, Danbolt NC: Differential developmental expression of the two rat brain glutamate transporter proteins GLAST and GLT. Eur J Neurosci 1997;9:1646-1655.

15 Utsumi M, Ohno K, Onchi H, Sato K, Tohyama M: Differential expression patterns of three glutamate transporters (GLAST, GLT1 and EAAC1) in the rat main olfactory bulb. Brain Res Mol Brain Res 2001;92:111.

16 Domercq M, Sanchez-Gomez MV, Areso P, Matute C: Expression of glutamate transporters in rat optic nerve oligodendrocytes. Eur J Neurosci 1999;11:2226-2236. 


\section{Cellular Physiology Cell Physiol Biochem 2016;39:2492-2500

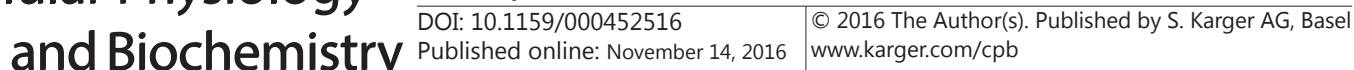 \\ Abousaab et al.: mTor Sensitive EAAT1 and EAAT2}

17 Domercq M, Matute C: Expression of glutamate transporters in the adult bovine corpus callosum. Brain Res Mol Brain Res 1999;67:296-302.

18 Gaillet S, Plachez C, Malaval F, Bezine MF, Recasens M: Transient increase in the high affinity [3H]-Lglutamate uptake activity during in vitro development of hippocampal neurons in culture. Neurochem Int 2001;38:293-301.

19 Plachez C, Danbolt NC, Recasens M: Transient expression of the glial glutamate transporters GLAST and GLT in hippocampal neurons in primary culture. J Neurosci Res 2000;59:587-593.

20 Rothstein JD, Martin L, Levey AI, Dykes-Hoberg M, Jin L, Wu D, Nash N, Kuncl RW: Localization of neuronal and glial glutamate transporters. Neuron 1994;13:713-725.

21 Barnett NL, Pow DV: Antisense knockdown of GLAST, a glial glutamate transporter, compromises retinal function. Invest Ophthalmol Vis Sci 2000;41:585-591.

22 Derouiche A, Rauen T: Coincidence of L-glutamate/L-aspartate transporter (GLAST) and glutamine synthetase (GS) immunoreactions in retinal glia: evidence for coupling of GLAST and GS in transmitter clearance. J Neurosci Res 1995;42:131-143.

23 Lawton DM, Furness DN, Lindemann B, Hackney CM: Localization of the glutamate-aspartate transporter, GLAST, in rat taste buds. Eur J Neurosci 2000;12:3163-3171.

24 Furness DN, Lehre KP: Immunocytochemical localization of a high-affinity glutamate-aspartate transporter, GLAST, in the rat and guinea-pig cochlea. Eur J Neurosci 1997;9:1961-1969.

25 Li HS, Niedzielski AS, Beisel KW, Hiel H, Wenthold RJ, Morley BJ: Identification of a glutamate/aspartate transporter in the rat cochlea. Hear Res 1994;78:235-242.

26 Takumi Y, Matsubara A, Danbolt NC, Laake JH, Storm-Mathisen J, Usami S, Shinkawa H, Ottersen OP: Discrete cellular and subcellular localization of glutamine synthetase and the glutamate transporter GLAST in the rat vestibular end organ. Neuroscience 1997;79:1137-1144.

27 Lee JA, Long Z, Nimura N, Iwatsubo T, Imai K, Homma H: Localization, transport, and uptake of D-aspartate in the rat adrenal and pituitary glands. Arch Biochem Biophys 2001;385:242-249.

28 Redecker P, Pabst H: Immunohistochemical study of the glutamate transporter proteins GLT-1 and GLAST in rat and gerbil pineal gland. J Pineal Res 2000;28:179-184.

29 Milton ID, Banner SJ, Ince PG, Piggott NH, Fray AE, Thatcher N, Horne CH, Shaw PJ: Expression of the glial glutamate transporter EAAT2 in the human CNS: an immunohistochemical study. Brain Res Mol Brain Res 1997;52:17-31.

30 Lehre KP, Danbolt NC: The number of glutamate transporter subtype molecules at glutamatergic synapses: chemical and stereological quantification in young adult rat brain. J Neurosci 1998;18:8751-8757.

31 Rothstein JD, Patel S, Regan MR, Haenggeli C, Huang YH, Bergles DE, Jin L, Dykes Hoberg M, Vidensky S, Chung DS, Toan SV, Bruijn LI, Su ZZ, Gupta P, Fisher PB: Beta-lactam antibiotics offer neuroprotection by increasing glutamate transporter expression. Nature 2005;433:73-77.

32 Gibb SL, Boston-Howes W, Lavina ZS, Gustincich S, Brown RH, Jr., Pasinelli P, Trotti D: A caspase-3-cleaved fragment of the glial glutamate transporter EAAT2 is sumoylated and targeted to promyelocytic leukemia nuclear bodies in mutant SOD1-linked amyotrophic lateral sclerosis. J Biol Chem 2007;282:32480-32490.

33 Rothstein JD, Dykes-Hoberg M, Pardo CA, Bristol LA, Jin L, Kuncl RW, Kanai Y, Hediger MA, Wang Y, Schielke JP, Welty DF: Knockout of glutamate transporters reveals a major role for astroglial transport in excitotoxicity and clearance of glutamate. Neuron 1996;16:675-686.

34 Tanaka K, Watase K, Manabe T, Yamada K, Watanabe M, Takahashi K, Iwama H, Nishikawa T, Ichihara N, Kikuchi T, Okuyama S, Kawashima N, Hori S, Takimoto M, Wada K: Epilepsy and exacerbation of brain injury in mice lacking the glutamate transporter GLT-1. Science 1997;276:1699-1702.

35 Vorwerk CK, Naskar R, Schuettauf F, Quinto K, Zurakowski D, Gochenauer G, Robinson MB, Mackler SA, Dreyer EB: Depression of retinal glutamate transporter function leads to elevated intravitreal glutamate levels and ganglion cell death. Invest Ophthalmol Vis Sci 2000;41:3615-3621.

36 Almilaji A, Pakladok T, Guo A, Munoz C, Foller M, Lang F: Regulation of the glutamate transporter EAAT3 by mammalian target of rapamycin mTOR. Biochem Biophys Res Commun 2012;421:159-163.

37 Martin DE, Hall MN: The expanding TOR signaling network. Curr Opin Cell Biol 2005;17:158-166.

38 Ueno M, Carvalheira JB, Tambascia RC, Bezerra RM, Amaral ME, Carneiro EM, Folli F, Franchini KG, Saad MJ: Regulation of insulin signalling by hyperinsulinaemia: role of IRS-1/2 serine phosphorylation and the mTOR/p70 S6K pathway. Diabetologia 2005;48:506-518. 


\section{Cellular Physiology Cell Physiol Biochem 2016;39:2492-2500

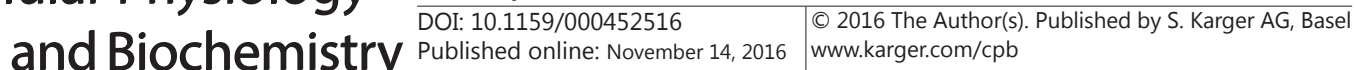 \\ Abousaab et al.: mTor Sensitive EAAT1 and EAAT2}

39 Mezey E, Rennie-Tankersley L, Potter JJ: Effect of leptin on liver alcohol dehydrogenase. Biochem Biophys Res Commun 2005;337:1324-1329.

40 Zhou H, Huang S: The complexes of mammalian target of rapamycin. Curr Protein Pept Sci 2010;11:409424.

41 Wouters BG, van den Beucken T, Magagnin MG, Koritzinsky M, Fels D, Koumenis C: Control of the hypoxic response through regulation of mRNA translation. Semin Cell Dev Biol 2005;16:487-501.

42 Yu C, Mao X, Li WX: Inhibition of the PI3K pathway sensitizes fludarabine-induced apoptosis in human leukemic cells through an inactivation of MAPK-dependent pathway. Biochem Biophys Res Commun 2005;331:391-397.

43 Fezai M, Warsi J, Lang F: Regulation of the $\mathrm{Na}+$,Cl- Coupled Creatine Transporter CreaT (SLC6A8) by the Janus Kinase JAK3. Neurosignals 2015;23:11-19.

44 Hosseinzadeh Z, Honisch S, Schmid E, Jilani K, Szteyn K, Bhavsar S, Singh Y, Palmada M, Umbach AT, Shumilina E, Lang F: The Role of Janus Kinase 3 in the Regulation of $\mathrm{Na}(+) / \mathrm{K}(+)$ ATPase under Energy Depletion. Cell Physiol Biochem 2015;36:727-740.

45 Cheng C, Glover G, Banker G, Amara SG: A novel sorting motif in the glutamate transporter excitatory amino acid transporter 3 directs its targeting in Madin-Darby canine kidney cells and hippocampal neurons. J Neurosci 2002;22:10643-10652.

46 Boehmer C, Henke G, Schniepp R, Palmada M, Rothstein JD, Broer S, Lang F: Regulation of the glutamate transporter EAAT1 by the ubiquitin ligase Nedd4-2 and the serum and glucocorticoid-inducible kinase isoforms SGK1/3 and protein kinase B. J Neurochem 2003;86:1181-1188.

47 Boehmer C, Palmada M, Rajamanickam J, Schniepp R, Amara S, Lang F: Post-translational regulation of EAAT2 function by co-expressed ubiquitin ligase Nedd4-2 is impacted by SGK kinases. J Neurochem 2006;97:911-921.

48 Gehring EM, Zurn A, Klaus F, Laufer J, Sopjani M, Lindner R, Strutz-Seebohm N, Tavare JM, Boehmer C, Palmada M, Lang UE, Seebohm G, Lang F: Regulation of the glutamate transporter EAAT2 by PIKfyve. Cell Physiol Biochem 2009;24:361-368.

49 Shigeri Y, Shimamoto K, Yasuda-Kamatani Y, Seal RP, Yumoto N, Nakajima T, Amara SG: Effects of threo-beta-hydroxyaspartate derivatives on excitatory amino acid transporters (EAAT4 and EAAT5). J Neurochem 2001;79:297-302.

50 Mohamed MR, Alesutan I, Foller M, Sopjani M, Bress A, Baur M, Salama RH, Bakr MS, Mohamed MA, Blin N, Lang F, Pfister M: Functional analysis of a novel I71N mutation in the GJB2 gene among Southern Egyptians causing autosomal recessive hearing loss. Cell Physiol Biochem 2010;26:959-966.

51 Warsi J, Abousaab A, Fezai M, Elvira B, Lang F: Regulation of Voltage Gated K+ Channel KCNE1/KCNQ1 by the Janus Kinase JAK3. Cell Physiol Biochem 2015;37:2476-2485.

52 Warsi J, Abousaab A, Lang F: Up-Regulation of Excitatory Amino Acid Transporters EAAT1 and EAAT2 by ss-Klotho. Neurosignals 2015;23:59-70.

53 Warsi J, Fezai M, Fores M, Elvira B, Lang F: Up-Regulation of Voltage Gated K+ Channels Kv1.3 and Kv1.5 by Protein Kinase PKB/Akt. Cell Physiol Biochem 2015;37:2454-2463.

54 Elvira B, Warsi J, Fezai M, Munoz C, Lang F: SPAK and OSR1 Sensitive Cell Membrane Protein Abundance and Activity of KCNQ1/E1 K+ Channels. Cell Physiol Biochem 2015;37:2032-2042.

55 Fezai M, Elvira B, Warsi J, Ben-Attia M, Hosseinzadeh Z, Lang F: Up-Regulation of Intestinal Phosphate Transporter NaPi-IIb (SLC34A2) by the Kinases SPAK and OSR1. Kidney Blood Press Res 2015;40:555-564.

56 Warsi J, Singh Y, Elvira B, Hosseinzadeh Z, Lang F: Regulation of Large Conductance Voltage-and Ca2+Activated K+ Channels by the Janus Kinase JAK3. Cell Physiol Biochem 2015;37:297-305.

57 Ahmed M, Salker MS, Elvira B, Umbach AT, Fakhri H, Saeed AM, Shumilina E, Hosseinzadeh Z, Lang F: SPAK Sensitive Regulation of the Epithelial Na Channel ENaC. Kidney Blood Press Res 2015;40:335-343.

58 Elvira B, Munoz C, Borras J, Chen H, Warsi J, Ajay SS, Shumilina E, Lang F: SPAK and OSR1 dependent downregulation of murine renal outer medullary K channel ROMK1. Kidney Blood Press Res 2014;39:353-360.

59 Warsi J, Dong L, Elvira B, Salker MS, Shumilina E, Hosseinzadeh Z, Lang F: SPAK dependent regulation of peptide transporters PEPT1 and PEPT2. Kidney Blood Press Res 2014;39:388-398.

60 Alesutan I, Voelkl J, Stockigt F, Mia S, Feger M, Primessnig U, Sopjani M, Munoz C, Borst O, Gawaz M, Pieske B, Metzler B, Heinzel F, Schrickel JW, Lang F: AMP-activated protein kinase alpha1 regulates cardiac gap junction protein connexin 43 and electrical remodeling following pressure overload. Cell Physiol Biochem 2015;35:406-418. 


\section{Cellular Physiology Cell Physiol Biochem 2016;39:2492-2500 \begin{tabular}{ll|l} 
DOI: 10.1159/000452516 & $\begin{array}{l}\text { O 2016 The Author(s). Published by S. Karger AG, Basel } \\
\text { www.karger.com/cpb }\end{array}$
\end{tabular} \\ Abousaab et al.: mTor Sensitive EAAT1 and EAAT2}

61 Almilaji A, Honisch S, Liu G, Elvira B, Ajay SS, Hosseinzadeh Z, Ahmed M, Munoz C, Sopjani M, Lang F: Regulation of the voltage gated K channel Kv1.3 by recombinant human klotho protein. Kidney Blood Press Res 2014;39:609-622.

62 Warsi J, Hosseinzadeh Z, Elvira B, Bissinger R, Shumilina E, Lang F: Regulation of ClC-2 activity by SPAK and OSR1. Kidney Blood Press Res 2014;39:378-387.

63 Almilaji A, Sopjani M, Elvira B, Borras J, Dermaku-Sopjani M, Munoz C, Warsi J, Lang UE, Lang F: Upregulation of the creatine transporter Slc6A8 by Klotho. Kidney Blood Press Res 2014;39:516-525.

64 Fezai M, Elvira B, Borras J, Ben-Attia M, Hoseinzadeh Z, Lang F: Negative regulation of the creatine transporter SLC6A8 by SPAK and OSR1. Kidney Blood Press Res 2014;39:546-554.

65 Munoz C, Pakladok T, Almilaji A, Elvira B, Decher N, Shumilina E, Lang F: Up-regulation of Kir2.1 (KCNJ2) by the serum \& glucocorticoid inducible SGK3. Cell Physiol Biochem 2014;33:491-500.

66 Fezai M, Ahmed M, Hosseinzadeh Z, Elvira B, Lang F: SPAK and OSR1 Sensitive Kir2.1 K+ Channels. Neurosignals 2015;23:20-33.

67 Warsi J, Elvira B, Bissinger R, Shumilina E, Hosseinzadeh Z, Lang F: Downregulation of peptide transporters PEPT1 and PEPT2 by oxidative stress responsive kinase OSR1. Kidney Blood Press Res 2014;39:591-599.

68 Gray C, Marie H, Arora M, Tanaka K, Boyde A, Jones S, Attwell D: Glutamate does not play a major role in controlling bone growth. J Bone Miner Res 2001;16:742-749.

69 Huggett J, Vaughan-Thomas A, Mason D: The open reading frame of the $\mathrm{Na}(+)$-dependent glutamate transporter GLAST-1 is expressed in bone and a splice variant of this molecule is expressed in bone and brain. FEBS Lett 2000;485:13-18.

70 Mason DJ, Suva LJ, Genever PG, Patton AJ, Steuckle S, Hillam RA, Skerry TM: Mechanically regulated expression of a neural glutamate transporter in bone: a role for excitatory amino acids as osteotropic agents? Bone 1997;20:199-205.

71 Nomura S, Takano-Yamamoto T: Molecular events caused by mechanical stress in bone. Matrix Biol 2000;19:91-96. 